\title{
Large-scale habitat model reveals a key role of large trees and protected areas in the metapopulation survival of the saproxylic specialist Cucujus cinnaberinus
}

\author{
Michał Bełcik $^{1}$ D . Jakub Goczał ${ }^{2} \cdot$ Michał Ciach $^{3}$
}

Received: 19 December 2018 / Revised: 26 August 2019 / Accepted: 11 September 2019 /

Published online: 18 September 2019

(C) The Author(s) 2019

\begin{abstract}
Deforestation for agricultural purposes and logging over centuries has resulted in a significant loss of forest cover and the deep structural and functional simplification of persistent European woodlands, which has led to a large-scale decline in biodiversity. Despite recent reforestation efforts in many regions of Europe, populations of numerous forest species remain unrecovered. Due to the loss of ecological continuity and the simplification of the ecosystem structure and functionality, the value of secondary forests in sustaining habitat specialists is being questioned. Here, we build a large-scale habitat suitability model to predict the current potential of forests to host populations of the flagship European saproxylic beetle Cucujus cinnaberinus. Our maximum entropy model revealed that the distribution of suitable habitats strongly corresponds to the occurrence of large and well-preserved forest complexes that are characterized by an ecological continuity of the stands. Among the analysed environmental variables, the mean tree diameter and distance to protected areas were the most important suitable habitat contributors. The optimum habitats were identified almost exclusively within some parts of the Carpathians and the northeastern part of the country, particularly in the Białowieża Forest, which include the best preserved European forests. Although a large number of small habitat patches was revealed across the country, these patches were highly scattered and had low predicted suitability. This study demonstrates that most woodlands are unsuitable for $C$. cinnaberinus, which points to the limited value of secondary forests for habitat specialists. Our findings emphasize the importance of large and intact forests with undisrupted ecological continuity as key areas for the persistence of the rare saproxylic beetle, which provokes questions about the effectiveness of reforestation as a tool for the conservation of forest habitat specialists.
\end{abstract}

Communicated by Nigel E. Stork.

Michał Bełcik

belcik@iop.krakow.pl

1 Institute of Nature Conservation, Polish Academy of Sciences, Mickiewicza 33, 31-120 Kraków, Poland

2 Institute of Forest Ecosystem Protection, Faculty of Forestry, University of Agriculture in Krakow, 29 Listopada 46, 31-425 Kraków, Poland

3 Department of Forest Biodiversity, Faculty of Forestry, Institute of Forest Ecology and Silviculture, University of Agriculture in Krakow, 29 Listopada 46, 31-425 Kraków, Poland 
Keywords MaxEnt $\cdot$ Umbrella species $\cdot$ Rewilding $\cdot$ Habitat restoration

\section{Introduction}

In recent centuries, human agricultural activity has led to the deforestation of the temperate region (Hanski et al. 1994; Glatzel 1999; Paillet et al. 2010). As a result, large parts of Europe have experienced a total loss of natural forest coverage, and the remaining fragments have become highly isolated. Furthermore, the current forest area primarily encompasses managed forests or tree plantations, which are characterized by a simplified and unified tree species composition, age and spatial structure (Glatzel 1999; Bengtsson et al. 2000). Another consequence of human activity in European forests is an interruption in the continuity of key ecological processes related to tree mortality, which causes the temporary or permanent depletion of dead wood resources (Kolb and Diekmann 2004; Fritz et al. 2008; Lassauce et al. 2011; Nordén et al. 2014). The abovementioned alterations of forests have resulted in biodiversity loss, which is manifested in reduced species richness, local species extinctions, changes in community structure and interruptions in meta-population connectivity (Rukke 2000; Kouki et al. 2001; Brunet and Isacsson 2009; Ranius and Roberge 2011).

After an era of intensive deforestation, the forest coverage in Europe has increased gradually. Forests were extended by 17.5 million ha between 1990 and 2015, i.e., approximately $0.33 \%$ per year (Forest Europe 2015), mainly due to intensive planting efforts led by the European Union (Gamborg and Larsen 2003; Bauhus et al. 2013; Forest Europe 2015). Moreover, forest management policies have been subject to a major paradigm shift through decades of intensive forest utilization to more sustainable and multifunctional forestry (Gamborg and Larsen 2003; Rametsteiner and Mayer 2004; Siry et al. 2005). Despite these positive trends, secondary growth forests still differ significantly from primeval conditions in terms of ecological complexity and biodiversity (Kuuluvainen et al. 1996; Weslien and Schroeder 1999; Grove 2002; Liira et al. 2007; Brumelis et al. 2011; Bouget and Parmain 2016). Such differences are a consequence of the disruption of ecological continuity and limitations of dead wood resources.

The term ecological continuity was adopted by Rose (Rose 1974) and has subsequently been widely applied as an indicator of forest ecological value. Although the definition of this term differs (Nordén and Appelqvist 2001), ecological continuity is most often used to describe forests characterized by long-term uninterrupted persistence and a low level of human-induced disturbance (Nordén and Appelqvist 2001; Kolb and Diekmann 2004; Nordén et al. 2014). Since both ecological continuity and dead wood abundance are considered crucial factors for biodiversity protection in forests (Grove 2002; Lassauce et al. 2011; Mikusińska et al. 2013; Kunttu et al. 2015), newly planted forests are expected to exhibit lower values for various forest species than for old-growth forests remnants. Although this hypothesis has been proven for various taxonomic groups (Bremer and Farley 2010; Paillet et al. 2010; Brumelis et al. 2011; Pawson et al. 2013; Bradshaw et al. 2015; Lachat and Müller 2018), there is a strong belief that secondary forests may help in biodiversity restoration.

Due to the large number of taxa, precise estimations of forest biodiversity represent a serious methodological problem and a consensus has not been reached on the indices that are reliable. Several different indicators of forest biodiversity at various levels have been proposed, including the total volume of dead wood, number of species, ecological 
continuity, habitat heterogeneity, habitat fragmentation, structural complexity and connectivity or occurrence of focal species (Barbati et al. 2014; Gao et al. 2015). Currently, one of the most frequently proposed concepts in biodiversity assessments involves the use of indicator species, i.e., habitat specialists or umbrella species (Roberge and Angelstam 2004; Sattler et al. 2014; Breckheimer et al. 2014; Mikoláš et al. 2015). Such an approach has several benefits, including a reduction of costs and clarity of management and conservation goals. Moreover, an indicator species approach may be advantageous because it is based on real species' responses to the quality of the environment quality and not technical estimators, such as habitat structure (e.g., dead wood volume). For forest biodiversity evaluations, saproxylic organisms, especially saproxylic beetles, are widely used as indicators (Jonsson and Jonsell 1999; Jonsell and Nordlander 2002; Ranius 2002; Smith et al. 2008; Lachat et al. 2012). Some wood-inhabiting beetles have specific habitat requirements and life-history traits that make them particularly sensitive to human-induced forest changes. Moreover, the occurrence of saproxylic beetles is well correlated with the presence of several other indicators, such as fungi (Linnakoski et al. 2012; Floren et al. 2015), other insects (Vindstad et al. 2014) and woodpeckers (Wesołowski 1995; Mikusiński et al. 2001; Tomiałojć and Wesołowski 2004).

Due to economical and historical circumstances, some forest fragments located mainly in the eastern part of Poland did not lose their ecological continuity over time (e.g., Białowieża Forest, Carpathian forests), whereas forests located in the western part of the country were markedly degraded or deforested by intensive utilization during World War II and now primarily include secondary forest planted after World War II. The aim of this study is to estimate the large-scale distribution pattern of suitable habitats of the flagship saproxylic species Cucujus cinnaberinus (Scopoli 1763). Given that the spread of the beetle has recently been observed in some parts of the species range, we investigated whether the results of large-scale forest habitat restoration could be beneficial for C. cinnaberinus and may enable the recovery of its population.

\section{Materials and methods}

\section{Targeted species}

Cucujus cinnaberinus constitutes a flagship species for saproxylic beetle conservation in Europe. The species is listed in the Bern Convention and strictly protected by law in most European countries across its distribution range. The species is listed as Near Threatened and close to qualifying for Vulnerable (Nieto et al. 2010). C. cinnaberinus is also included in the II and IV annexes to the Habitat Directive, and the status of its population and habitat has become crucial for the identification and monitoring of protected areas included in the Nature 2000 network across the entire European Union.

Prior to the twenty-first century, knowledge of the distribution and ecology of $C$. cinnaberinus was limited and the species was perceived as an extremely rare "relict beetle" associated with natural or even primeval forests (Speight 1989; Eriksson 2000). However, in recent years, large-scale spreading of the species was observed in Western and Southern Europe. The species markedly expanded its range in Germany (Reibnitz 2008; Esser and Mainda 2015; Hörren and Tolkiehn 2016) and Austria (Eckelt et al. 2014), entered the Netherlands (Teunissen and Vendrig 2012; Noordijk et al. 2013) and Belgium (Crevecoeur et al. 2017) and reached Northern France (Fuchs et al. 2014). C. cinnaberinus was found to 
inhabit anthropogenic habitats, such as abandoned poplar plantations and non-native black locust Robinia pseudoacacia stands (Vrezec et al. 2017). However, these latter findings resulted in their exclusion from a recent list of "primeval forest relict beetles" (Eckelt et al. 2018). Recent changes in European forest management policy, including the application of close-to-nature silviculture, increased the dead wood resources and promoted reforestation and rewilding efforts, which have had a positive effect on saproxylic organisms, such as C. cinnaberinus. Nevertheless, empirical data clearly documenting this effect are still insufficient.

Cucujus cinnaberinus is considered an umbrella species, and its protection serves to protect a wide community of co-occurring saproxylic organisms (Mazzei et al. 2011; Horák et al. 2012). Currently, the occurrence of $C$. cinnaberinus has been confirmed in most European countries (Horák and Chobot 2009; Nieto et al. 2010; Horák et al. 2010), including newly discovered populations in Southern Europe (Kovács et al. 2012; Fuchs et al. 2014; Šag et al. 2016; Vrezec et al. 2017). The species inhabits various types of deciduous and mixed forest, both in the mountains and lowlands. C. cinnaberinus prefers large and sun-exposed dead wood of various deciduous and coniferous trees characterized by a moderate to high moisture content and an intermediate stage of decay (Horák et al. 2010, 2012; Goczał and Rossa 2017; Vrezec et al. 2017).

Although C. cinnaberinus is no longer considered a relict species, it still serves as an indicator of forest biodiversity. As a saproxylic specialist, this species tends to perish rapidly with forest alterations due to interruptions in the dead wood supply. On the other hand, current data from Western and Southern Europe suggest that their populations may be restored if an appropriate rewilding method is applied. Furthermore, its occurrence is relatively simple to detect, and surveys can be conducted throughout entire seasons (Buchholz 2012). These characteristics make $C$. cinnaberinus a proper candidate for a model species to assess the effect of structural changes of forest habitats on saproxylic organisms.

\section{Study area}

Poland is a central European country $\left(312,679 \mathrm{~km}^{2}\right)$ with high forest coverage (Fig. 1). At the end of the 18th century, forests accounted for as much as $40 \%$ of the Polish territory (The State Forests Information Centre 2010). Nevertheless, due to intensive exploitation during World War II between 1939 and 1945, forest cover dropped by half to approximately $21 \%$ in 1946 (The State Forests Information Centre 2010). Large parts of old-growth and natural deciduous forest were replaced with fast-growing coniferous monocultures, although this trend this varied markedly between regions across the country, with intensive forest utilization and structural alterations occurring in the western parts of the country and vast tracts of old-growth natural forest with a long ecological continuity remaining in eastern and southern Poland. After World War II, the first National Plan of Afforestation was established to support the most degraded and completely deforested areas. Since that time, the forest area in Poland has increased and currently encompasses $29.5 \%$ of the country (Central Statistical Office 2015). As a result, previously ecologically degraded western parts of Poland currently present the highest forest coverage nationwide (Central Statistical Office 2015). However, these restored forests still represent heavily transformed secondary managed woodlands. Although eastern Poland has lower forest coverage than western Poland (ca. 30\% vs. 39\%), it includes the best preserved old-growth and primeval forests in Europe. 


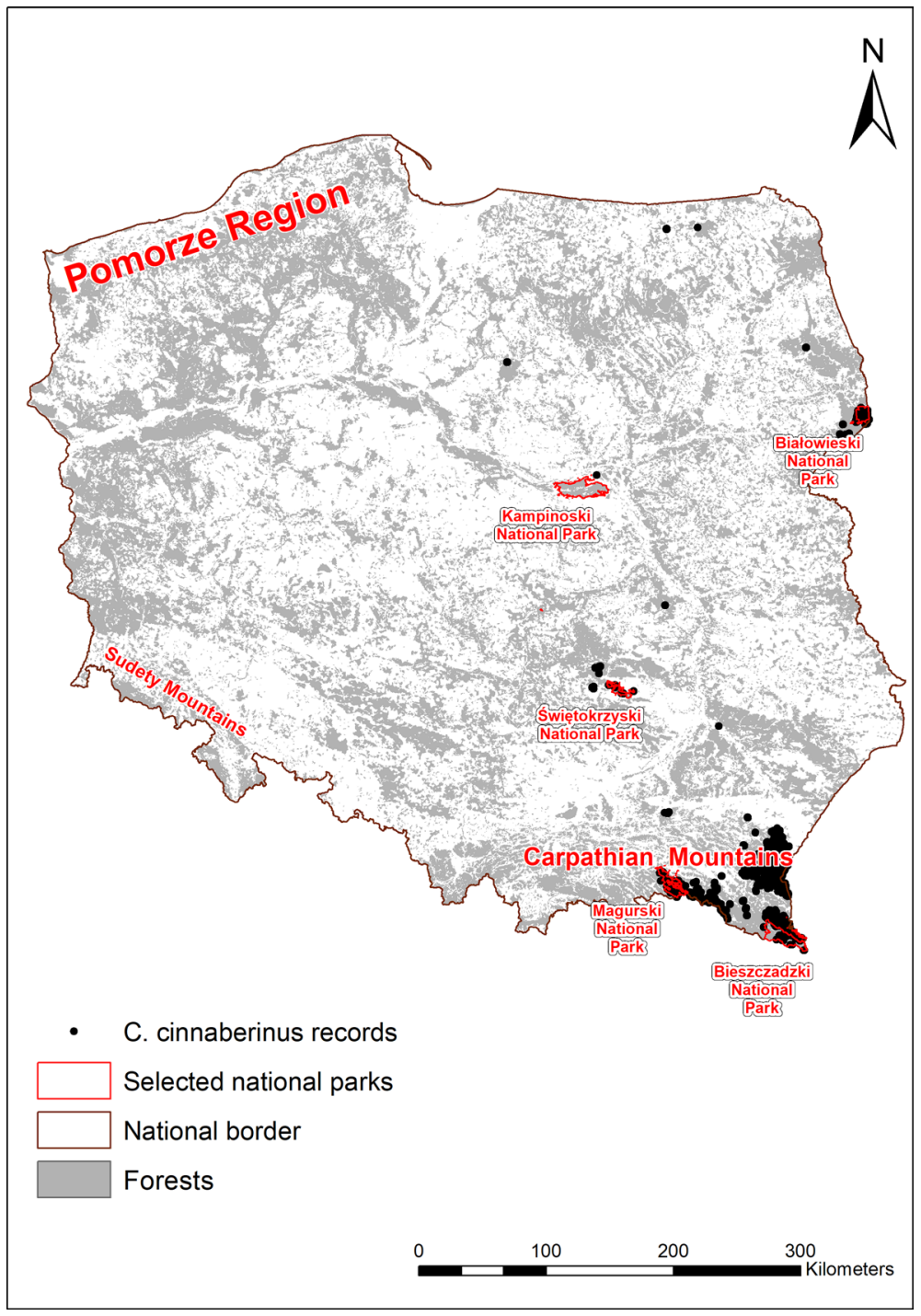

Fig. 1 Forests in Poland, Cucujus cinnaberinus presence records and the most important locations mentioned in the text

\section{Presence data}

We used all available sources of $C$. cinnaberinus presence records, including published articles and reports (Trzeciak 2011; Miłkowski 2012; Smolis et al. 2012; Buchholz et al. 2013; Olbrycht et al. 2014; Plewa et al. 2014; Marczak 2016), and unpublished data from governmental agencies (Regional Directorates for Environmental Protection), State Forests National Forest Holdings and national park authorities, which are obligated by law to collect data on the species' occurrence. Due to the implementation of the Habitats Directive (Official Journal of the European Communities 1992) and establishment of the Natura 2000 
network of protected areas in Poland, potential habitats have been surveyed since 2004 for the purpose of preparing management plans. Due to the conservation value of the species and legal requirements, $C$. cinnaberinus was one of the targeted species. All conducted surveys provided reliable data on the current distribution of $C$. cinnaberinus in Poland. In total, 794 records collected up to 2016 were used in the analyses (Fig. 1).

\section{Environmental background data}

Based on an analysis of the ecological literature on saproxylic insects (Speight 1989; Franc et al. 2007; Bouget et al. 2014), a set of environmental variables was selected with the potential to affect the occurrence of $C$. cinnaberinus (Table 1). Layers representing distance to urban areas (as a land cover class), roads and protected areas (national parks and nature reserves) were created using the state spatial features geodatabase (BDOO, Polish central geodesy database, http://www.codgik.gov.pl), which includes vector layers for every major geographical and spatial feature in the country. A distance matrix was selected to account for the degree of human disturbance based on the raster resolution chosen for the analysis. For data describing tree stands, we have used the Bureau for Forest Management and Geodesy Forest data bank (https://www.bdl.lasy.gov.pl), which is a data repository that contains information about all state owned and private forests in Poland. These data have been collected for the preparation of Forest Management Plans and represent the official National Forest Inventory, which includes detailed descriptions of a wide variety of forest stand parameters, habitat types and soil parameters available at the stand scale. The data collection methodology is regulated by their official technical manual (The State Forests Information Centre 2012), which ensures that data collection is uniform for the whole country and the environmental data are a reliable source for country-wide analyses. Data from the BDOO database have similar characteristics and were collected from countrywide land use surveys; thus, this database is a reliable source of information at the landscape scale. Light pollution as a proxy of human presence and activity (Longcore and Rich 2004) was determined based on the visible infrared imaging radiometer suite supplied by the Earth Observations Group (NOAA National Geophysical Data Center). The raster layer contains the average radiance based on night-time data and was expressed in nanowatts per square centimetre per steradian $\left(\mathrm{nW} / \mathrm{cm}^{2} \times \mathrm{SR}\right)$.

All layers used in the analyses were converted into ASCII file format with the same cell size $(50 \mathrm{~m})$ using ArcGIS software (ESRI, Redlands, USA). This size has been chosen to capture the spatial complexity of forest stands because rasters generated via this method accurately represent forest stand boundaries. An increase in cell size would produce a raster that would not spatially match the forest stand boundaries, thus resulting in a loss of information due to generalization. A total of 13 variables (Table 1) were used in modelling. The correlations between variables were evaluated via a Pearson correlation analysis $(r>0.5$ for all variable pairs). To include the described complexity of Polish forests, our model has been created to reflect the extent of the country, including both forested and non-forested areas. All of the environmental layers (in PUWG 1992 coordinate system) were clipped to the boundaries of the country. In case of non-forested areas, all of the attributes concerning the forest stands (e.g., mean diameter at breast height, mean density, etc.) were assigned a value of zero. 


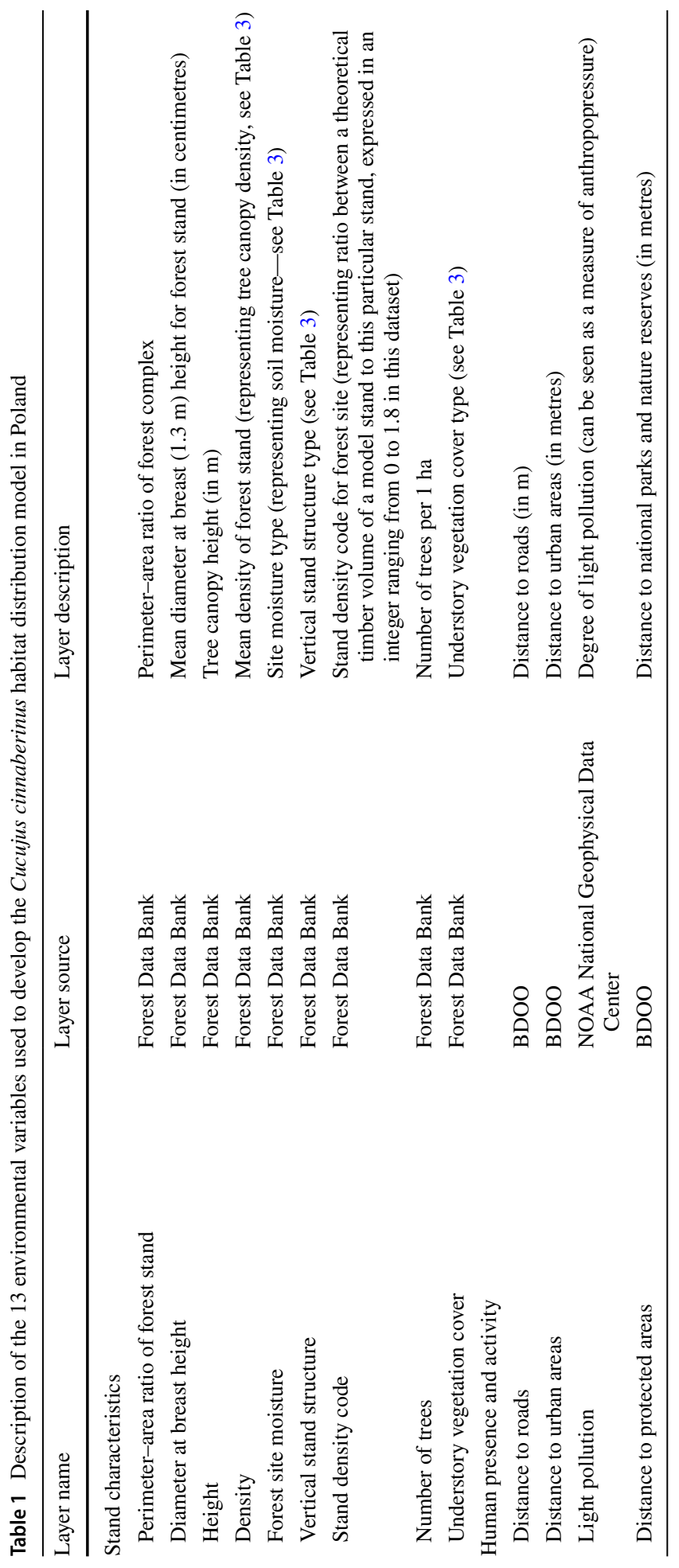




\section{Modelling approach and model validation}

To determine the habitat parameters that can be used to predict the $C$. cinnaberinus distribution, we applied species distribution modelling using maximum entropy models in MaxEnt ver. 3.3.3 k software (Phillips et al. 2006). The following settings were used: a 15-fold cross validation with 5000 iterations, a logistic output to generate response curves and jackknife results, random seeding and a regularisation multiplier (fixed at 1).

A Receiver Operating Characteristic (ROC) curve was evaluated to determine the model's predictive ability, and the evaluation focused on the Area Under the Curve (AUC) of the ROC curve. An AUC value close to 0.5 represents a totally random model, while an AUC value close to 1 represents perfect discrimination (Fielding and Bell 1997). To minimize the risk of over-fitting and obtain an unbiased prediction (Abid and Williams 2010), we applied jackknife tests to estimate the variables that were most important for model prediction. Predictor variables with a percentage of contribution exceeding 100/K (where $\mathrm{K}$ is the number of predictors) were considered to have high explanatory power (Mac Nally 2000, 2002).

\section{Dealing with spatial autocorrelation}

The Maximum Entropy method is among the most widely used modelling approaches in cases with sparse, irregularly sampled data and minor location errors (Phillips et al. 2009). Although the method focuses on presence-only data, the lack of systematic sampling of an area of interest may lead to a spatial bias (Kramer-Schadt et al. 2013) because of the overrepresentation of species records from carefully checked areas relative to the locations where no research was carried out. Because $C$. cinnaberinus is a targeted species for preparing the management plans for both protected areas and managed forests, potential habitats were carefully inspected for the species' occurrence by using the same methodology (Buchholz 2012). This approach minimizes the potential bias resulting from the omission of a large part of potentially occupied areas. As a result, data collected for the purpose of this study represent the current distribution of $C$. cinnaberinus.

To overcome the potential sampling bias effect caused by the spatial clumping of presence data, we applied the following widely used method designed to deal with a spatial autocorrelation: background manipulation with a bias file (Kramer-Schadt et al. 2013; Phillips et al. 2009). This approach relies on simulating a dataset that provides an independent means on predictive performance assessment (Kramer-Schadt et al. 2013). This dataset was created by generating a random point layer with the same amount of points as the original forest observations in $4 \mathrm{~km}$ buffer zones, and these layers were then rasterized and converted to ASCII file format. By generating random points, this approach minimizes the bias that may occur due to spatial autocorrelation between presence data and environmental layers, and it is recognized to improve the goodness of fit of the model (Syfert et al. 2013; Stolar and Nielsen 2014).

\section{Selecting suitable areas}

We have used the resulting Maxent modelling output to identify suitable forest patches as well as areas that could potentially be colonized by $C$. cinnaberinus. First, we identified forests occupied by the species by drawing a $50 \mathrm{~m}$ buffer (corresponding to the model raster resolution) around each of the known occurrence points and selected forest patches that 
fell within this buffer as occupied areas. To determine the potentially suitable forest stands for this species, we have selected areas where the Maxent predicted suitability was $>50 \%$ (Yan et al. 2018). We also identified forests patches that could be potentially colonized by the species. Since the dispersal distance for $C$. cinnaberinus is not known, we have used an average distance between nearest known localities as a proxy of the movement ability (median $=517 \mathrm{~m}$, quartile range: $258.1-1192.7$ ). The received value corresponds well with known median dispersal distances for other saproxylic beetles of a similar size (Brouwers and Newton 2009; Zauli 2014). Every suitable forest stand that fell within this distance was considered to be potentially available for colonization.

\section{Results}

\section{Species habitat distribution}

Plotted model predictions indicated that the most suitable areas for C. cinnaberinus coincided with the largest and most intact forest complexes of the eastern part of Poland (Fig. 2), which were located mainly in the Carpathian Mountains and the northeastern region (i.e., the Białowieża Forest). Suitable habitat patches were also identified in the southern-central part of the country (Fig. 2), including forest complexes of the Świętokrzyskie Mts National Park (see Fig. 1). A large number of small and highly scattered habitat patches across the country that could potentially be suitable to harbour $C$. cinnaberinus populations was also observed. However, most of these sites had low predicted suitability and were isolated and beyond the predicted movement abilities for the species (Fig. 2). Large parts of central and western Poland revealed no suitable habitats for C. cinnaberinus despite their relatively extensive forest coverage. The average AUC for the replicate runs was $0.943 \pm 0.008 \mathrm{SD}$, indicating that the proposed model accurately predicted the actual species habitat distribution.

\section{Potential for dispersion}

The mean area of the forest complexes occupied by $C$. cinnaberinus was 32.02 ha (SD $=37.93$, range: $0.01-346.72$, median $=23.04)$ and did not significantly differ $(F=182.2$, $\mathrm{p}=0.89)$ from the mean area of suitable forest patches at 25.20 ha $(\mathrm{SD}=232.89$, range: $0.002-17,192.78$, median $=4.39$ ha). The median distance between occupied forest complexes was $407.77 \mathrm{~m}$ (quartile range: $99.75-1136.98)$ and differed significantly $(\mathrm{F}=144.1$, $\mathrm{p}=0.01$ ) from the median distance between the suitable forest patches at $69.87 \mathrm{~m}$ (quartile range: 11.59-239.21). Although the mean distance between suitable habitat patches was smaller than the mean distance between occupied forest complexes, most clusters of suitable habitat patches were located over the current species distribution and outside the potential movement range (Fig. 2).

\section{Contribution of environmental variables to the model}

The maximum entropy model indicated that the most important variables $(\geq 10 \%$ of contribution) in both the training and final models were the mean diameter at breast height of the forest stand, distance to the protected areas, amount of light pollution and amount of moisture of the forest stand (Figs. 3 and 4 and Table 2). 


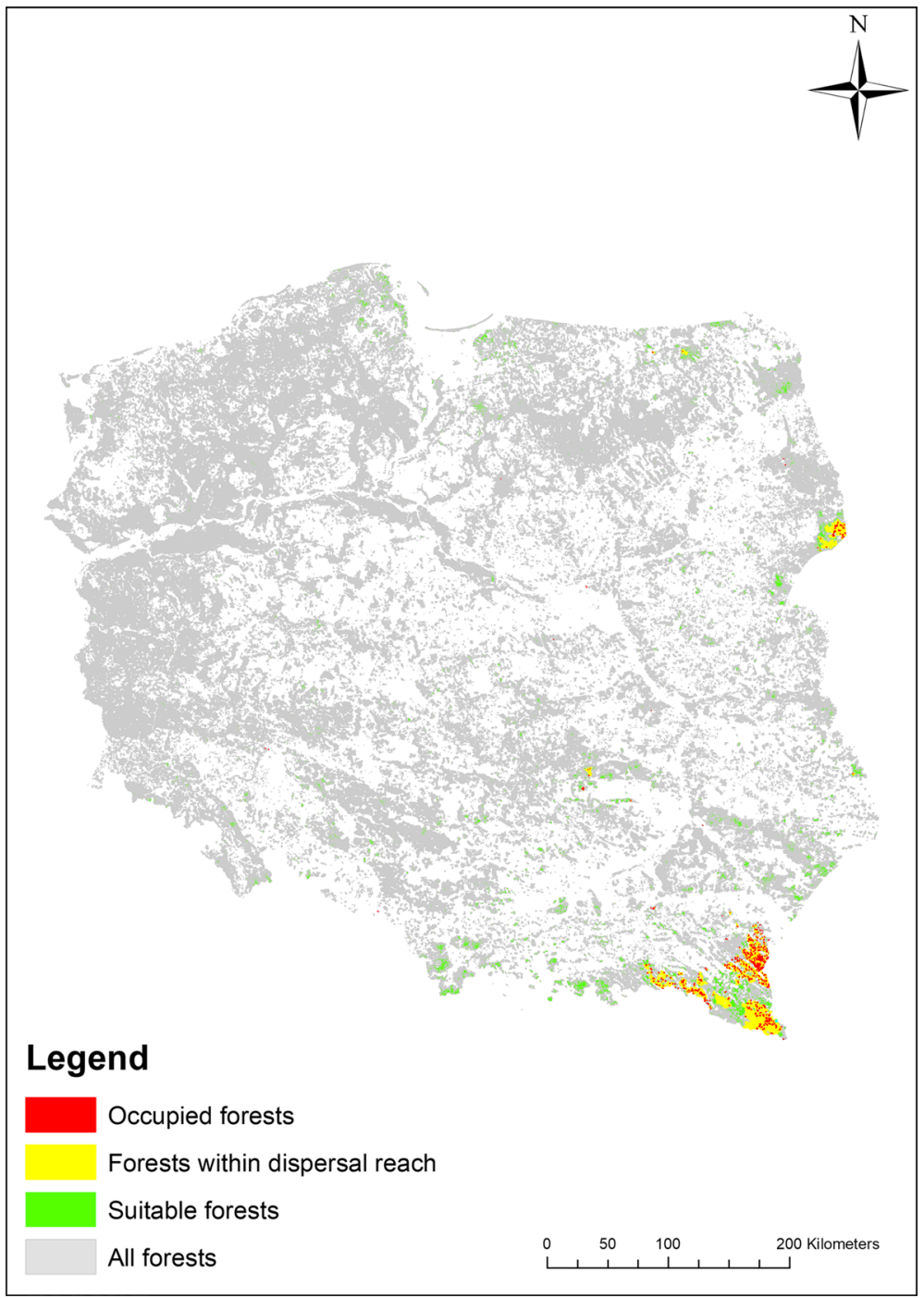

Fig. 2 Predicted suitable forest patches and areas for colonization for Cucujus cinnaberinus in Poland derived from a maximum entropy model

\section{Single environmental variables response}

The habitat suitability for $C$. cinnaberinus increased with the mean diameter at breast height and reached its highest value at above $50 \mathrm{~cm}$ (Fig. 3). The probability of the occurrence of suitable habitats decreased rapidly with increasing distance to the protected areas and increasing level of light pollution, which is a proxy of human activity (Fig. 3). The probability of occurrence of suitable habitats was the highest in forest stands characterized by a sparse and moderate density but dropped sharply where there was no density (e.g., 
Fig. 3 Effect of the mean diameter at breast height $(1.3 \mathrm{~m})$ for the forest stand, distance to protected areas and amount of light pollution on the habitat suitability for Cucujus cinnaberinus
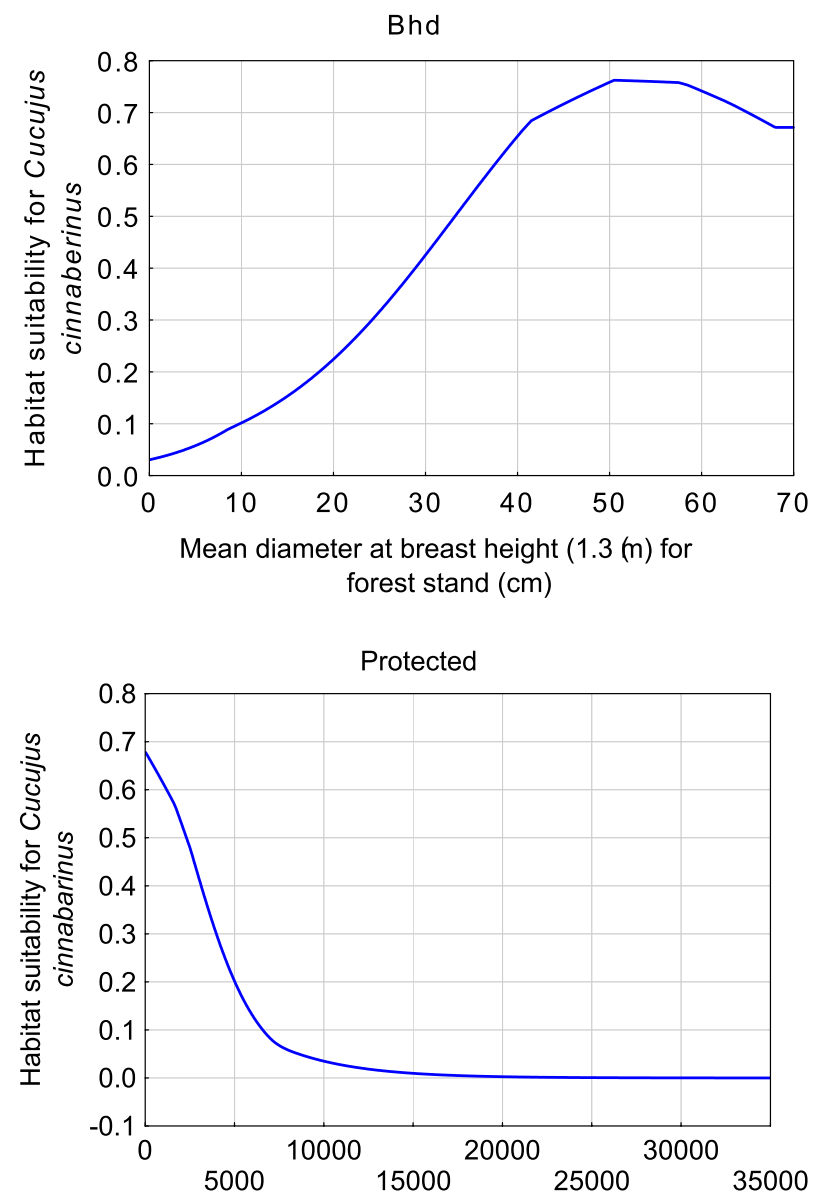

Distance to national parks and nature reserves $(\mathrm{m})$

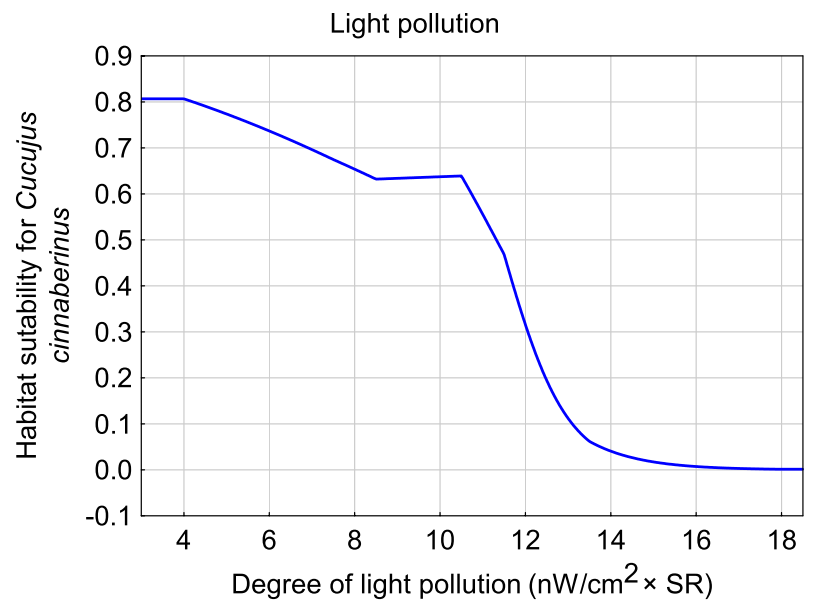



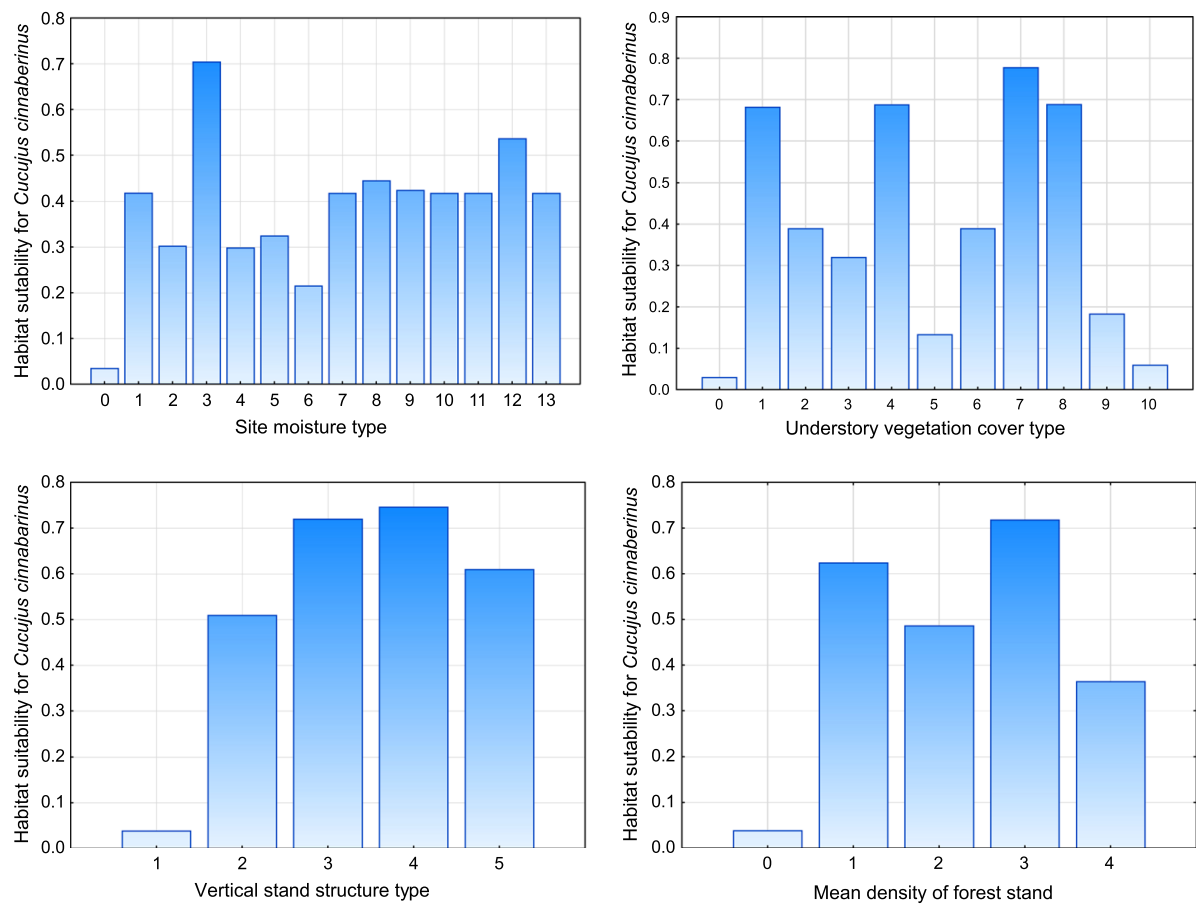

Fig. 4 Effect of the environmental variables on Cucujus cinnaberinus on habitat suitability. Site moisture (0-No forest cover; 1-Moist; 2-Drained wet; 3-very moist; 4-wet swamps; 5-wet; 6-drained swamps; 7-dry; 8-flooded wet; 9-riparian flooded; 10-riparian non-flooded; 11-heavily drained swamps; 12-heavily wet swamps; and 13-riparian heavily flooded), understory vegetation cover type (0-no forest cover; 1 -noxious plants; 3-heavy turf; 4-turf; 5-herbaceous; litter 6-naked; 7-light vegetation cover; 8-disturbed; 9-moss carpet; and 10-moss and blueberries), vertical stand structure type (1-no forest cover; 2-normal stand; 3-harvested and regenerated stand; 4-multi-storey stand; and 5-harvested stand) and mean density of a forest stand ( 0 - no forest cover; 1 - sparse density (30\% of forest floor covered by a canopy shadow); 2 - patchy density ( $50 \%$ of forest floor covered by a canopy shadow); 3-moderate density (70\% of forest floor covered by a canopy shadow); and 4-full density ( $100 \%$ of forest floor covered by a canopy shadow)

clearcuts) or a high density (e.g., dense plantations, Fig. 4). The species inhabited forest stands of a wide array of vegetation cover types (including herbs and low and high shrubs) but was less frequent in areas with bare litter or mossy ground cover (Fig. 4). Furthermore, the species tended to prefer multi-storey stands characterized by high moisture (e.g., very moist sites, Fig. 4).

\section{Discussion}

Our large-scale study revealed that the optimal habitats for the flagship saproxylic specialist $C$. cinnaberinus included large forest complexes located mostly in the southeastern and northeastern parts of Poland (Fig. 2). These areas are characterized by the occurrence of forests with long-lasting ecological continuity, with Białowieża Forest and certain 
Table 2 Percent contribution of environmental variables used to develop the Cucujus cinnaberinus habitat distribution model

\begin{tabular}{lll}
\hline Variable & $\begin{array}{l}\text { Percent con- } \\
\text { tribution }\end{array}$ & $\begin{array}{l}\text { Permutation } \\
\text { importance }\end{array}$ \\
\hline Diameter at breast height & 37.4 & 13.6 \\
Distance to protected areas & 18.3 & 42.2 \\
Light pollution & 12.3 & 34.4 \\
Forest site moisture & 10.0 & 1.2 \\
Type of understory vegetation cover & 8.2 & 4.5 \\
Vertical stand structure & 5.7 & 0.1 \\
Mean density of forest stand & 3.8 & 0.0 \\
Forest stand height & 2.0 & 0.1 \\
Distance to roads & 1.1 & 1.9 \\
Stand density code for forest site & 0.5 & 0.0 \\
Distance to inhabited areas & 0.5 & 1.8 \\
Number of trees per 1 ha & 0.2 & 0.1 \\
Perimeter-area ratio of forest stand & 0.0 & 0.1 \\
\hline
\end{tabular}

Carpathian forests representing examples of areas with permanent natural forest coverage since the last glaciation and encompassing the largest and best preserved forests in all of Europe (Bernadzki et al. 1998; Mitchell and Cole 1998; Jaworski et al. 2002; Kucharzyk 2008; Zimny et al. 2017). Moreover, our analyses indicated that suitable habitats are currently overlapped with areas of high conservation priority that are protected as national parks (Białowieża, Bieszczady and Magura national parks; Fig. 1). Other potentially suitable habitats were highly scattered across the country, although they coincided with the distribution of well-preserved forest remnants, including forests of the Świętokrzyskie Mts National Park (see Fig. 1), which are currently known for hosting isolated populations of $C$. cinnaberinus.

Our analyses indicated that secondary forests located mainly in the western part of Poland seem to be unsuitable for $C$. cinnaberinus despite the high total forest coverage and the presence of large forest complexes in this part of the country (Fig. 2). One explanation is that secondary forests still do not have features characteristic of natural habitats and the period of nearly 70 years since their reforestation is not sufficient to reproduce the characteristic features of natural ecosystems. Managed and protected forests of Poland differ significantly in dead wood resources, with the average volume of dead wood at $5.5 \mathrm{~m}^{3}$ / ha and $37.4 \mathrm{~m}^{3} /$ ha in managed forests and national parks, respectively (Bureau for Forest Management and Geodesy 2015). Moreover, human-induced deforestation has likely led to the interruption of the forest's continuity and total extinction of local populations of the studied species. A lack of source population caused by the large-scale habitat fragmentation and limited mobility of $C$. cinnaberinus may prevent population recovery. In the case of saproxylic organisms, even a temporary gap in availability of suitable dead wood hosts could lead to rapid population collapses (Speight 1989; Ranius and Fahrig 2006; Seibold et al. 2015), especially for habitat specialists that are only able to inhabit specific microhabitats.

Limited dispersal ability is a crucial feature for all living organisms that influences the population dynamics, gene flow and extinction risk of local populations (Ranius 2006). This ability is particular important in the case of saproxylic organisms, which usually 
occupy small and heavily fragmented habitat patches (Brouwers and Newton 2009; Zauli 2014). A large number of saproxylic insects have declining populations and are considered endangered due to low habitat availability in heavily transformed landscapes (Ranius 2006). Unfortunately, direct data on the dispersal abilities of saproxylic insects are extremely rare. Nevertheless, some indirect methods for estimating a species' dispersal potential are available. Given that occurrence of a given species is usually shaped by colonization and extinction processes, it may serve as an indirect measure of a species' colonization potential (Ranius 2006). The results of our study based on the distribution pattern of the saproxylic specialist $C$. cinnaberinus showed that the occupied and potentially suitable forest patches do not differ in size and that the clustering of the latter group is even higher. However, the majority of suitable habitat patches were located far from the occupied areas and beyond the potential movement reach of the species, which might indicate that the biggest obstacle in the dispersal of $C$. cinnaberinus throughout the country is the lack of suitable patches between optimal habitats, which are needed to realize long-distance colonization. One possible solution to this problem is to create, within the species migration reach, stepping stone habitats located between larger conservation structures, such as national parks or forest reserves. Such habitats may be realized by increasing the retention of dead wood of preferable properties in managed forests along the designed dispersal routes. Another possible solution is to conduct species introductions in forested areas that are characterized by high predicted suitability and located beyond the range of the potential spontaneous dispersion of $C$. cinnaberinus. The latter solution might potentially bring faster results, although the stepping stone approach will certainly provide benefits for other dead wood-dependent organisms, which potentially co-occur with $C$. cinnaberinus, a proper umbrella species.

In some parts of Europe, $C$. cinnaberinus may temporarily benefit from some secondary habitats where the recent abandonment of forest fragments (e.g., poplar plantations) contain a high accumulation of dead wood resources. However, based on a long-term perspective, this approach may form an ecological trap that does not ensure the continuity of some key processes related to tree mortality and decomposition, which are essential for the long-term survival of saproxylic organisms (Hunter 1990; Grove 2002). Our study provides evidence that the conservation of old-growth forests, occurrence of natural disturbances, and creation of small sun-exposed gaps in the forest canopy are integral components of the lifecycle of temperate forests (Rademacher et al. 2004; Mitchell 2005; Senf and Seidl 2017) and may ensure the long-term survival of $C$. cinnaberinus populations.

A preferred association between old-growth forests and $C$. cinnaberinus distributions is also highlighted by the contribution of the most important environmental variables to its habitat model. The obtained model indicated that old forests characterized by the occurrence of large trees (based on the mean diameter at breast height in our model) located inside (or near) protected areas (based on the distance to protected areas in our model) are potentially optimal habitats for $C$. cinnaberinus. Other factors associated with high habitat suitability were tree density and stand structure. Our study indicates that species preferred multi-storey stands with moderate density but avoided clear-cut areas as well as highdensity stands. Complex vertical structures with open-canopy patches are typical of oldgrowth natural forests, where the gap dynamic ensures the proper insolation of the stand interior below the canopy (Schelhaas et al. 2003). Although roads and inhabited areas had a weak effect, light pollution had a clear negative impact. This feature is widely used as a measure of anthropopressure (Longcore and Rich 2004; Gaston et al. 2013). Our results suggest that when modelling saproxylic insect distributions, light pollution may be a reliable indicator of human pressure on forest habitats if a better proxy is not available. 
The forests of Europe have been subject to long-term anthropogenic modifications that have resulted in the extensive retreat of forest coverage across the continent and structural alterations of remaining forests by forest management practices (Grove 2002; Paillet et al. 2010). Poland is no exception. Despite the successful conservation of old-growth forests in eastern regions of the country, the woodlands of western Poland have experienced heavy anthropogenic transformations, which have deeply simplified their structure and interrupted the ecological continuity. Although habitat restoration, including the implementation of reforestation, reconstruction of natural species compositions and application of more nature-friendly management practices, has been performed for approximately 70 years, the secondary forests of western Poland are still unsuitable habitats for flagship saproxylic habitat specialists. These findings provoke questions about the results of reforestation and the ecological value of secondary forests. Certain evidence has shown the positive effect of habitat restoration in Poland for several threatened animal species, such as the recolonization of western Poland of the grey wolf Canis lupus (Nowak et al. 2017) and European Beaver Castor fiber (Dzięciołowski and Gozdziewski 1999). However, none of the saproxylic forest relict species have colonized western Poland thus far. Populations of old-growth relicts, such as Rhysodes sulcatus or Boros schneideri, remain restricted to a few localities in eastern Poland, and their distribution pattern resembles the actual distribution of C. cinnaberinus (Polish Biodiversity Information Network 2018). Therefore, we suggest that the initial widespread optimism for rewilding as an effective method of nature conservation (Helmer et al. 2015) should be verified by considering the presence of habitat specialists. Unfortunately, few comprehensive studies have clearly showed the actual value of restored forest habitats for such organisms. Therefore, we strongly encourage further comprehensive studies on the effectiveness of reforestation and rewilding in the conservation of highly specialized forest species.

Acknowledgements We are immensely grateful to Piotr Skórka for providing valuable comments on the earlier version of the manuscript. We would also like to express our gratitude to the Bureau for Forest Management and Geodesy Forest Data Bank, Regional Directorates for Environmental Protection, State Forests National Forest Holding and National Parks for proving data for this study. Michał Bełcik was supported by the Grant Sonata Bis 4 no. 2014/14/E/NZ8/00165 from the National Science Centre, Poland and by the Institute of Nature Conservation, Polish Academy of Sciences (Kraków, Poland) through the institute's statutory funds and grant funding for $\mathrm{PhD}$ students and young scientists provided by the Institute of Botany, Polish Academy of Sciences (Kraków, Poland). Jakub Goczał and Michał Ciach were supported by the Ministry of Science and Higher Education of the Republic of Poland under the statutory grants DS-3416/ ZOLEKL/2017 and DS-3421/ZBL/2017, respectively.

Open Access This article is distributed under the terms of the Creative Commons Attribution 4.0 International License (http://creativecommons.org/licenses/by/4.0/), which permits unrestricted use, distribution, and reproduction in any medium, provided you give appropriate credit to the original author(s) and the source, provide a link to the Creative Commons license, and indicate if changes were made. 


\section{Appendix}

See Table 3.

Table 3 Values for the categorical stand variables used to develop the Cucujus cinnaberinus habitat distribution model

\begin{tabular}{|c|c|c|}
\hline Variable & Value & Description \\
\hline Forest site moisture & 0 & No forest cover \\
\hline Forest site moisture & 1 & Moisture \\
\hline Forest site moisture & 2 & Drained wet \\
\hline Forest site moisture & 3 & Very moisture \\
\hline Forest site moisture & 4 & Wet swamps \\
\hline Forest site moisture & 5 & Wet \\
\hline Forest site moisture & 6 & Drained swamps \\
\hline Forest site moisture & 7 & Dry \\
\hline Forest site moisture & 8 & Flooded wet \\
\hline Forest site moisture & 9 & Riparian flooded \\
\hline Forest site moisture & 10 & Riparian non-flooded \\
\hline Forest site moisture & 11 & Heavily drained swamps \\
\hline Forest site moisture & 12 & Heavily wet swamps \\
\hline Forest site moisture & 13 & Riparian heavily flooded \\
\hline Vertical stand structure & 1 & No forest cover \\
\hline Vertical stand structure & 2 & Normal stand \\
\hline Vertical stand structure & 3 & Harvested and regenerated stand \\
\hline Vertical stand structure & 4 & Multi-storey stand \\
\hline Vertical stand structure & 5 & Harvested stand \\
\hline Understory vegetation cover & 0 & No forest cover \\
\hline Understory vegetation cover & 1 & Noxious plants \\
\hline Understory vegetation cover & 2 & Heavy turf \\
\hline Understory vegetation cover & 3 & Turf \\
\hline Understory vegetation cover & 4 & Herbaceous \\
\hline Understory vegetation cover & 5 & Litter \\
\hline Understory vegetation cover & 6 & Naked \\
\hline Understory vegetation cover & 7 & Light vegetation cover \\
\hline Understory vegetation cover & 8 & Degenerated \\
\hline Understory vegetation cover & 9 & Moss carpet \\
\hline Understory vegetation cover & 10 & Moss and blueberries \\
\hline Density & 0 & No forest cover \\
\hline Density & 1 & Sparse density ( $30 \%$ of forest floor covered by a canopy shadow) \\
\hline Density & 2 & Patchy density ( $50 \%$ of forest floor covered by a canopy shadow) \\
\hline Density & 3 & Moderate density ( $70 \%$ of forest floor covered by a canopy shadow) \\
\hline Density & 4 & Full density ( $100 \%$ of forest floor covered by a canopy shadow) \\
\hline
\end{tabular}




\section{References}

Abid H, Williams L (2010) Jacknife. In: Salkind N (ed) Encyclopedia of research design. Sage, Thousand Oaks

Barbati A, Marchetti M, Chirici G, Corona P (2014) European forest types and forest Europe SFM indicators: tools for monitoring progress on forest biodiversity conservation. For Ecol Manag 321:145-157. https://doi.org/10.1016/j.foreco.2013.07.004

Bauhus J, Puettmann K, Kühne C (2013) Close-to-nature forest management in Europe: does it support complexity and adaptability of forest ecosystems. In: Messier C, Puettmann K, Coates K (eds) Managing forests as complex adaptive systems: building resilience to the challenge of global change, the Earths. Routledge, London, pp 187-213

Bengtsson J, Nilsson SG, Franc A, Menozzi P (2000) Biodiversity, disturbances, ecosystem function and management of European forests. For Ecol Manag 132:39-50. https://doi.org/10.1016/S0378 $-1127(00) 00378-9$

Bernadzki E, Bolibok L, Brzeziecki B et al (1998) Compositional dynamics of natural forests in the Bialowieza National Park, northeastern Poland. J Veg Sci 9:229-238. https://doi.org/10.2307/3237122

Bouget C, Parmain G (2016) Effects of landscape design of forest reserves on Saproxylic beetle diversity. Conserv Biol 30:92-102. https://doi.org/10.1111/cobi.12572

Bouget C, Larrieu L, Brin A (2014) Key features for saproxylic beetle diversity derived from rapid habitat assessment in temperate forests. Ecol Indic 36:656-664. https://doi.org/10.1016/j.ecolind.2013.09.031

Bradshaw RH, Jones CS, Edwards SJ, Hannon GE (2015) Forest continuity and conservation value in Western Europe. Holocene 25:194-202. https://doi.org/10.1177/0959683614556378

Breckheimer I, Haddad NM, Morris WF et al (2014) Defining and evaluating the umbrella species concept for conserving and restoring landscape connectivity. Conserv Biol 28:1584-1593. https://doi. org/10.1111/cobi. 12362

Bremer LL, Farley KA (2010) Does plantation forestry restore biodiversity or create green deserts? A synthesis of the effects of land-use transitions on plant species richness. Biodivers Conserv 19:38933915. https://doi.org/10.1007/s10531-010-9936-4

Brouwers N, Newton A (2009) Movement rates of woodland invertebrates: a systematic review of empirical evidence. Insect Conserv Divers 2:10-22. https://doi.org/10.1111/j.1752-4598.2008.00041.x

Brumelis G, Jonsson BG, Kouki J et al (2011) Forest naturalness in Northern Europe: perspectives on processes, structures and species diversity. Silva Fenn 45:807-821. https://doi.org/10.14214/sf.446

Brunet J, Isacsson G (2009) Restoration of beech forest for saproxylic beetles-effects of habitat fragmentation and substrate density on species diversity and distribution. Biodivers Conserv 18:2387-2404. https://doi.org/10.1007/s10531-009-9595-5

Buchholz L (2012) Zgniotek cynobrowy Cucujus cinnaberinus. In: Makomaska-Juchiewicz M, Baran P (eds) Monitoring gatunków zwierząt. Przewodnik metodyczny, vol. II. GIOŚ, Warszawa, pp 417-446

Buchholz L, Kuberski Ł, Michalski R et al (2013) Chrząszcze (Coleoptera) z załącznika II Dyrektywy Siedliskowej na obszarze projektowanego Turnickiego Parku Narodowego i w jego okolicach. Rocz Bieszczadzkie 21:297-317

Bureau for Forest Management and Geodesy (2015) The national forest inventory. Bureau for Forest Management and Geodesy, Sćkocin Stary

Central Statistical Office (2015) Forestry 2015. Central Statistical Office, Warsaw

Commission European (1992) Council Directive 92/43/ECC on the conservation of natural habitats and of wild fauna and flora. Off J Eur Union 94:40-52

Crevecoeur L, Thomaes A, Hendrickx R (2017) Eerste waarneming van de habitatrichtlijnsoort vermiljoenkever Cucujus cinnaberinus in Limburg en België! Natuuronderzoek Limbg 2017:26-29

Dzięciołowski R, Gozdziewski J (1999) The reintroduction of European beaver, castor fiber, in Poland. Beaver protection, management, and utilization in Europe and North America. Springer, Boston, pp 31-35

Eckelt A, Paill W, Straka U (2014) Viel gesucht und oft gefunden. Der scharlachkäfer Cucujus cinnaberinus (Scopoli, 1763) und seine aktuelle verbreitung in Österreich. Wissenschaftliches Jahrb der Tiroler Landesmuseen 7:145-159

Eckelt A, Müller J, Bense U et al (2018) 'Primeval forest relict beetles' of Central Europe: a set of 168 umbrella species for the protection of primeval forest remnants. J Insect Conserv 22:15-28. https:// doi.org/10.1007/s10841-017-0028-6

Eriksson P (2000) Long term variation in population densities og saproxylic beetles at the river Dalälven, Sweden. (sv). Entomol Tidskr 121:119-135

Esser J, Mainda T (2015) Der Scharlachrote Plattkäfer Cucujus cinnaberinus (Scopoli, 1763) in Brandenburg. Naturschutz und Landschaftspfl Brand 18-22 
Fielding AH, Bell JF (1997) A review of methods for the assessment of prediction errors in conservation presence/absence models. Environ Conserv 24:38-49. https://doi.org/10.1017/S0376892997000088

Floren A, Krüger D, Müller T et al (2015) Diversity and interactions of wood-inhabiting fungi and beetles after deadwood enrichment. PLoS ONE 10:1-17. https://doi.org/10.1371/journal.pone.0143566

Forest Europe (2015) State of Europe's Forests 2015. In: Ministerial conference on the protection of forests in Europe. Liaison Unit Madrid, Madrid, p 314

Franc N, Götmark F, Økland B, Nordén B, Paltto H (2007) Factors and scales potentially important for saproxylic beetles in temperate mixed oak forest. Biol Conserv 135:86-98. https://doi.org/10.1016/j. biocon.2006.09.021

Fritz Ö, Gustafsson L, Larsson K (2008) Does forest continuity matter in conservation? — a study of epiphytic lichens and bryophytes in beech forests of southern Sweden. Biol Conserv 141:655-668. https ://doi.org/10.1016/j.biocon.2007.12.006

Fuchs L, Callot H, Godinat G (2014) Cucujus cinnaberinus (Scopoli, 1763), nouvelle espèce pour la faune de France (Coleoptera: Cucujidae). L'Entomologiste 70:213-221

Gamborg C, Larsen JB (2003) 'Back to nature' - a sustainable future for forestry? For Ecol Manag 179:559-571. https://doi.org/10.1016/S0378-1127(02)00553-4

Gao T, Nielsen AB, Hedblom M (2015) Reviewing the strength of evidence of biodiversity indicators for forest ecosystems in Europe. Ecol Indic 57:420-434. https://doi.org/10.1016/j.ecolind.2015.05.028

Gaston KJ, Bennie J, Davies TW, Hopkins J (2013) The ecological impacts of nighttime light pollution: a mechanistic appraisal. Biol Rev 88:912-927. https://doi.org/10.1111/brv.12036

Glatzel G (1999) Historic forest use and its possible implications to recently accelerated tree growth in Central Europe. In: Karjaleinen T, Spieker H, Laroussine O (eds) Causes and consequences of accelerated tree growth in Europe. European Forest Institute Proceedings, Joensuu, pp 65-67

Goczał J, Rossa R (2017) Dead wood complexity shapes the pattern of the occurrence of threatened saproxylic beetle Cucujus cinnaberinus. Pol J Ecol 65:158-165. https://doi.org/10.3161/15052249PJ E2017.65.1.014

Grove SJ (2002) Saproxylic insect ecology and the sustainable management of forests. Annu Rev Ecol Syst 33:1-23. https://doi.org/10.1146/annurev.ecolsys.33.010802.150507

Hanski I, Kuussaari M, Nieminen M (1994) Metapopulation structure and migration in the butterfly Melitaea cinxia. Ecology 75:747-762. https://doi.org/10.2307/1941732

Helmer W, Saavedra D, Sylvén M, Schepers F (2015) Rewilding Europe: a new strategy for an old continent. Rewilding European Landscapes. Springer, Cham, pp 171-190

Horák J, Chobot K (2009) Worldwide distribution of saproxylic beetles of the genus Cucujus fabricius. In: Buse J, Alexander K, Ranius T, Assmann T (eds) Saproxylic beetles: their role and diversity in European woodland and tree habitats: proceedings of the 5th symposium and workshop on the conservation. Pensoft Publishers, Sofia, pp 189-206

Horák J, Vávrová E, Chobot K (2010) Habitat preferences influencing populations, distribution and conservation of the endangered saproxylic beetle Cucujus cinnaberinus (Coleoptera: Cucujidae) at the landscape level. Eur J Entomol 107:81-88. https://doi.org/10.14411/eje.2010.011

Horák J, Chumanová E, Hilszczański J (2012) Saproxylic beetle thrives on the openness in management: a case study on the ecological requirements of Cucujus cinnaberinus from Central Europe. Insect Conserv Divers 5:403-413. https://doi.org/10.1111/j.1752-4598.2011.00173.x

Hörren T, Tolkiehn J (2016) Erster Nachweis von Cucujus cinnaberinus (Scopoli, 1763) in SchleswigHolstein-eine FFH-Art erschließt sich Lebensräume in Norddeutschland (Coleoptera: Cucujidae). Entomol Zeitschrift Schwanfeld 126(4):208-209

Hunter ML (1990) Wildlife, forests, and forestry: principles of managing forests for biological diversity. Prentice-Hall, New York

Jaworski A, Kołodziej Z, Porada K (2002) Structure and dynamics of stands of primeval character in selected areas of the Bieszczady National Park. J For Sci 48:185-201

Jonsell M, Nordlander G (2002) Insects in polypore fungi as indicator species: a comparison between forest sites differing in amounts and continuity of dead wood. For Ecol Manag 157:101-118. https ://doi.org/10.1016/S0378-1127(00)00662-9

Jonsson BG, Jonsell M (1999) Exploring potential biodiversity indicators in boreal forests. Biodivers Conserv 8:1417-1433. https://doi.org/10.1023/a:1008900309571

Kolb A, Diekmann M (2004) Effects of environment, habitat configuration and forest continuity on the distribution of forest plant species. J Veg Sci 15(2):199-208. https://doi.org/10.1658/11009233(2004)015\%5b0199:EOEHCA\%5d2.0.CO;2

Kouki J, Löfman S, Martikainen P et al (2001) Forest fragmentation in Fennoscandia: linking habitat requirements of wood-associated threatened species to landscape and habitat changes. Scand J For Res 16:27-37. https://doi.org/10.1080/028275801300090564 
Kovács T, Németh T, Merkl O (2012) Beetles new to Albania, Croatia and Serbia (Coleoptera: Elateridae, Cucujidae, Melandryidae, Cerambycidae). Folia Hist Musei Matraensis 36:43-44

Kramer-Schadt S et al (2013) The importance of correcting for sampling bias in MaxEnt species distribution models. Divers Distrib 19:1366-1379

Kucharzyk S (2008) Forest of primeval character in the Bieszczady National Park. Rocz Bieszczadzkie 16:19-32

Kunttu P, Junninen K, Kouki J (2015) Dead wood as an indicator of forest naturalness: a comparison of methods. For Ecol Manag 353:30-40. https://doi.org/10.1016/j.foreco.2015.05.017

Kuuluvainen T, Leinonen K, Nygren M, Penttinen A (1996) Statistical opportunities for comparing stand structural heterogeneity in managed and primeval forests: an example from boreal spruce forest in southern Finland. Silva Fenn. https://doi.org/10.14214/sf.a9243

Lachat T, Müller J (2018) Importance of primary forests for the conservation of saproxylic insects. Springer, Cham, pp 581-605

Lachat T, Wermelinger B, Gossner MM et al (2012) Saproxylic beetles as indicator species for deadwood amount and temperature in European beech forests. Ecol Indic 23:323-331. https://doi. org/10.1016/j.ecolind.2012.04.013

Lassauce A, Paillet Y, Jactel H, Bouget C (2011) Deadwood as a surrogate for forest biodiversity: metaanalysis of correlations between deadwood volume and species richness of saproxylic organisms. Ecol Indic 11:1027-1039

Liira J, Sepp T, Parrest O (2007) The forest structure and ecosystem quality in conditions of anthropogenic disturbance along productivity gradient. For Ecol Manag 250:34-46. https://doi.org/10.1016/j.forec o.2007.03.007

Linnakoski R, Wilhelm de Beer ZB, Niemelä P, Wingfield MJ (2012) Associations of conifer-infesting bark beetles and fungi in Fennoscandia. Insects 3:200-227. https://doi.org/10.3390/insects3010200

Longcore T, Rich C (2004) Ecological light pollution. Front Ecol Environ 2:191-198

Mac Nally R (2000) Regression and model-building in conservation biology, biogeography and ecology: the distinction between - and reconciliation of - 'predictive' and 'explanatory' models. Biodivers Conserv 9:655-671. https://doi.org/10.1023/A:1008985925162

Mac Nally R (2002) Multiple regression and inference in ecology and conservation biology: further comments on identifying important predictor variables. Biodivers Conserv 11:1397-1401. https://doi. org/10.1023/A:1016250716679

Marczak D (2016) Zgniotek cynobrowy Cucujus cinnaberinus w Kampinoskim Parku Narodowym i uwagi do jego monitoringu. Stud i Mater Cent Edukac Przyr w Rogowie 49:142-152

Mazzei A, Bonacci T, Contarini E et al (2011) Rediscovering the 'umbrella species' candidate Cucujus cinnaberinus (Scopoli, 1763) in Southern Italy (Coleoptera Cucujidae), and notes on bionomy. Ital J Zool 78:264-270. https://doi.org/10.1080/11250003.2010.485210

Mikoláš M, Svitok M, Tejkal M et al (2015) Evaluating forest management intensity on an umbrella species: Capercaillie persistence in central Europe. For Ecol Manag 354:26-34. https://doi.org/10.1016/j.forec o.2015.07.001

Mikusińska A, Zawadzka B, Samojlik T et al (2013) Quantifying landscape change during the last two centuries in Białowieża Primeval Forest. Appl Veg Sci 16:217-226. https://doi.org/10.1111/j.1654109X.2012.01220.x

Mikusiński G, Gromadzki M, Chylarecki P (2001) Woodpeckers as indicators of forest bird diversity. Conserv Biol 15:208-217. https://doi.org/10.1046/j.1523-1739.2001.99236.X

Miłkowski M (2012) Zgniotek cynobrowy Cucujus cinnaberinus (Scopoli, 1763) (Coleoptera: Cucujidae) w Radomiu. Kulon 17:139-142

Mitchell FJG (2005) How open were European primeval forests? Hypothesis testing using palaeoecological data. J Ecol 93:168-177

Mitchell FJG, Cole E (1998) Reconstruction of long-term successional dynamics of temperate woodland in Bialowieza Forest, Poland. J Ecol 86:1042-1059. https://doi.org/10.1046/j.1365-2745.1998.00323.x

Nieto A, Mannerkoski I, Putchkov A et al (2010) Cucujus cinnaberinus. IUCN Red List of Threatened Species. https://doi.org/10.2305/iucn.uk.2010-1.rlts.t5935a11921415.en

Noordijk J, Colijn E, Teunissen D, Vendrig C (2013) De Vermiljoenkever: een voor Nederland nieuwe habitatrichtlijnsoort geeft aanwijzingen voor bosbeheer. Levende Nat 114:187-190

Nordén B, Appelqvist T (2001) Conceptual problems of ecological continuity and its bioindicators. Biodivers Conserv 10:779-791. https://doi.org/10.1023/A:1016675103935

Nordén B, Dahlberg A, Brandrud TE et al (2014) Effects of ecological continuity on species richness and composition in forests and woodlands: a review. Écoscience 21:34-45. https://doi. org/10.2980/21-1-3667 
Nowak S, Mysłajek RW, Szewczyk M et al (2017) Sedentary but not dispersing wolves Canis lupus recolonizing western Poland (2001-2016) conform to the predictions of a habitat suitability model. Divers Distrib 23:1353-1364. https://doi.org/10.1111/ddi.12621

Olbrycht T, Melke A, Michalski R, Kuberski Ł (2014) Występowanie zgniotka cynobrowego Cucujus cinnaberinus (Scopoli, 1763) (Coleoptera, Cucujidae) w Bieszczadach i Beskidzie Niskim. Rocz Bieszczadzkie 22:311-320

Paillet Y, Bergès L, HjÄltén J et al (2010) Biodiversity differences between managed and unmanaged forests: meta-analysis of species richness in Europe. Conserv Biol 24:101-112. https://doi.org/10.111 1/j.1523-1739.2009.01399.x

Pawson SM, Brin A, Brockerhoff EG et al (2013) Plantation forests, climate change and biodiversity. Biodivers Conserv 22:1203-1227. https://doi.org/10.1007/s10531-013-0458-8

Phillips SJ, Anderson RP, Schapire RE (2006) Maximum entropy modeling of species geographic distributions. Ecol Model 190:231-259. https://doi.org/10.1016/j.ecolmodel.2005.03.026

Phillips SJ, Dudík M, Elith J et al (2009) Sample selection bias and presence-only distribution models: implications for background and pseudo-absence data. Ecol Appl 19:181-197. https://doi. org/10.1890/07-2153.1

Plewa R, Hilszczański J, Jaworski T, Sierpiński A (2014) Nowe i rzadko spotykane chrząszcze (Coleoptera) saproksyliczne wschodniej Polski. Wiadomości Entomol 30:85-96

Polish Biodiversity Information Network (2018) Biodiversity Map Database. http://baza.biomap.pl. Accessed 10 Nov 2018

Rademacher C, Neuert C, Grundmann V et al (2004) Reconstructing spatiotemporal dynamics of Central European natural beech forests: the rule-based forest model BEFORE. For Ecol Manag 194:349_ 368. https://doi.org/10.1016/j.foreco.2004.02.022

Rametsteiner E, Mayer P (2004) Sustainable forest management and Pan: European Forest Policy. Ecol Bull. https://doi.org/10.2307/20113296

Ranius T (2002) Osmoderma eremita as an indicator of species richness. Biodivers Conserv 11:931941. https://doi.org/10.1023/A:1015364020043

Ranius T (2006) Measuring the dispersal of saproxylic insects: a key characteristic for their conservation. Popul Ecol 48:177-188. https://doi.org/10.1007/s10144-006-0262-3

Ranius T, Fahrig L (2006) Targets for maintenance of dead wood for biodiversity conservation based on extinction thresholds. Scand J For Res 21:201-208. https://doi.org/10.1080/02827580600688269

Ranius T, Roberge J-M (2011) Effects of intensified forestry on the landscape-scale extinction risk of dead wood dependent species. Biodivers Conserv 20:2867-2882. https://doi.org/10.1007/s1053 $1-011-0143-8$

Reibnitz J (2008) Cucujus cinnaberinus sicher in Baden-Württemberg (Coleoptera: Cucujidae). Mitteilungen Entomologischer Verein Stuttgart 43:54-59

Roberge JM, Angelstam P (2004) Usefulness of the umbrella species concept as a conservation tool. Conserv Biol 18:76-85. https://doi.org/10.1111/j.1523-1739.2004.00450.x

Rose F (1974) The epiphytes of oak. In: Morris M, Perring F (eds) The British Oak. Its history and natural history. EW Classey, Faringdon, pp 250-273

Rukke BA (2000) Effects of habitat fragmentation: increased isolation and reduced habitat size reduces the incidence of dead wood fungi beetles in a fragmented forest landscape. Ecography (Cop) 23:492-502. https://doi.org/10.1111/j.1600-0587.2000.tb00305.x

Šag M, Turić N, Vignjević G et al (2016) Prvi nalaz rijetkih i ugroženih saproksilnih kornjaša, Cucujus cinnaberinus (Scopoli, 1763), Rhysodes sulcatus (Fabricius, 1787) i Omoglymmius germari (Ganglbauer, 1891) u Parku prirode Kopački rit. Nat Croat 25:249-258

Sattler T, Pezzatti GB, Nobis MP et al (2014) Selection of multiple umbrella species for functional and taxonomic diversity to represent urban biodiversity. Conserv Biol 28:414-426. https://doi. org/10.1111/cobi.12213

Schelhaas M-J, Nabuurs G-J, Schuck A (2003) Natural disturbances in the European forests in the 19th and 20th centuries. Glob Chang Biol 9:1620-1633. https://doi.org/10.104 6/j.1365-2486.2003.00684.x

Seibold S, Brandl R, Buse J et al (2015) Association of extinction risk of saproxylic beetles with ecological degradation of forests in Europe. Conserv Biol 29:382-390. https://doi.org/10.1111/cobi.12427

Senf C, Seidl R (2017) Natural disturbances are spatially diverse but temporally synchronized across temperate forest landscapes in Europe. Glob Chang Biol 38:42-49. https://doi.org/10.1111/gcb.13897

Siry JP, Cubbage FW, Ahmed MR (2005) Sustainable forest management: global trends and opportunities. For Policy Econ 7:551-561. https://doi.org/10.1016/j.forpol.2003.09.003 
Smith GF, Gittings T, Wilson M et al (2008) Identifying practical indicators of biodiversity for standlevel management of plantation forests. Biodivers Conserv 17:991-1015. https://doi.org/10.1007/ s10531-007-9274-3

Smolis A, Kadej M, Gutowski JM et al (2012) Zgniotek cynobrowy Cucujus cinnaberinus (Scopoli, 1763) (Insecta: Coleoptera: Cucujidae)—rozmieszczenie, ekologia i problemy ochrony oraz nowe stanowiska w Polsce południowo-zachodniej. Chrońmy Przyrodę Ojczystą 68:332-346

Speight MCD (1989) Saproxylic invertebrates and their conservation. Nat Environ 42:1-79

Stolar J, Nielsen SE (2014) Accounting for spatially biased sampling effort in presence-only species distribution modelling. Divers Distrib 21:595-608

Syfert MM et al (2013) The effects of sampling bias and model complexity on the predictive performance of MaxEnt species distribution models. PLoS ONE 8(2):e55158. https://doi.org/10.1371/ journal.pone. 0055158

Teunissen A, Vendrig C (2012) Een Nederlandse populatie van de zeldzame en beschermde vermiljoenkever Cucujus cinnaberinus (Coleoptera: Cucujidae). Entomol Ber 72:2018-2021

The State Forests Information Centre (2010) Raport o stanie lasów w Polsce 2009. The State Forests Information Centre, Warsaw

The State Forests Information Centre (2012) Instrukcja Urządzania Lasu. The State Forests Information Centre, Warsaw

Tomiałojć L, Wesołowski T (2004) Diversity of the Bialowieza Forest avifauna in space and time. J Ornithol 145:81-92. https://doi.org/10.1007/s10336-003-0017-2

Trzeciak A (2011) Zgniotek cynobrowy Cucujus cinnaberinus (Scopoli, 1763) (Coleoptera: Cucujidae) w okolicach Dębicy. Wiadomości Entomol 30:185-186

Vindstad OPL, Schultze S, Jepsen JU et al (2014) Numerical responses of saproxylic beetles to rapid increases in dead wood availability following geometrid moth outbreaks in sub-arctic mountain birch forest. PLoS ONE. https://doi.org/10.1371/journal.pone.0099624

Vrezec A, Ambrožič Š, Kobler A et al (2017) Cucujus cinnaberinus (Scopoli, 1763) at its terra typica in Slovenia: historical overview, distribution patterns and habitat selection. Nat Conserv 19:219-229. https://doi.org/10.3897/natureconservation.19.12645

Weslien J, Schroeder LM (1999) Population levels of bark beetles and associated insects in managed and unmanaged spruce stands. For Ecol Manag 115:267-275. https://doi.org/10.1016/S0378 $-1127(98) 00405-8$

Wesołowski T (1995) Value of Białowieża Forest for the conservation of white-backed woodpecker Dendrocopos leucotos in Poland. Biol Conserv 71:69-75. https://doi.org/10.1016/0006-3207(94)00022-I

Yan Z, Teng M, He W et al (2018) Improving conservation effectiveness of nature reserve for nosed monkey, a niche-based approach. Ecol Evol 2:9315-9325

Zauli A (2014) Using odour traps for population monitoring and dispersal analysis of the threatened saproxylic beetles Osmoderma eremita and Elater ferrugineus in central Italy. J Insect Conserv 18:801-813. https://doi.org/10.1007/s10841-014-9687-8

Zimny M, Latałowa M, Pędziszewska A (2017) The Late-Holocene history of forests in the Strict Reserve of Białowieża National Park. In: Keczyński A (ed) The forests of the strict reserve of Białowieża National Park. Białowieski Park Narodowy, Białowieża, pp 29-59

Publisher's Note Springer Nature remains neutral with regard to jurisdictional claims in published maps and institutional affiliations. 